Témoigner Témoigner. Entre histoire et mémoire

Getuigen Revue pluridisciplinaire de la Fondation Auschwitz

$126 \mid 2018$

Questions sur l'avenir du travail de mémoire

\title{
Le sec et l'humide, de Jonathan Littell, mis en scène par Guy Cassiers
}

Le sec et l'humide (Guy Cassiers naar Jonathan Littell)

\section{Guy Zelis}

\section{(2) OpenEdition}

1 Journals

\section{Édition électronique}

URL : https://journals.openedition.org/temoigner/6435

DOI : $10.4000 /$ temoigner.6435

ISSN : 2506-6390

Traduction(s) :

Le sec et l'humide (Guy Cassiers naar Jonathan Littell) - URL : https://journals.openedition.org/

temoigner/7025 [nl]

Éditeur :

Éditions du Centre d'études et de documentation Mémoire d'Auschwitz, Éditions Kimé

Édition imprimée

Date de publication : 2 avril 2018

Pagination : 23-26

ISBN : 978-2-930953-06-9

ISSN : 2031-4183

Référence électronique

Guy Zelis, «Le sec et l'humide, de Jonathan Littell, mis en scène par Guy Cassiers », Témoigner. Entre histoire et mémoire [En ligne], 126 | 2018, mis en ligne le 24 janvier 2022, consulté le 04 février 2022. URL : http://journals.openedition.org/temoigner/6435; DOI : https://doi.org/10.4000/temoigner.6435 


\section{"This Kind of Love" Descriptions of Lesbian Behaviour in Nazi Concentration Camps}

$\rightarrow$ Claudia Schoppmann

Translation from the
Elisabeth Tutschek

(1) All translations from German
sources are Elisabeth Tutschek's.

(2) In fact this category

prostitutes (mostly of German 20,000 Sinti and Roma that were held in a "family camp".

\section{DEROGATORY DESCRIPTIONS OF LESBIAN BEHAVIOUR}

B esides the confirmed but rare cases in which homosexuality was one of

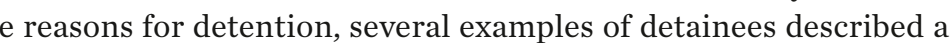
esbian can be found in memoirs of former fellow inmates. Even though the women described displayed this behaviour in camp, to conclude that they assigned themselves a lesbian identity outside the camp would not be accurate. Nor would it be correct to conclude - as is sometimes assumed - that they had been arrested due to their homosexuality. All these deeply stigmatising and pejorative descriptions have one thing in common: they are external attributions. As far as I can tell, testimonies by lesbian women about their imprisonment in camps do not exist. Besides, what is problematic about this genre is that, in each individual case, it cannot be determined if and to what extent events were possibly fictionalized.

One of the most detailed descriptions of lesbian conduct in the memoir genre can be found in Fania Fénelons' novel Das Mädchenorchester in Auschwitz [The Girls Orchestra of Auschwitz], which reached high circulation and was also turned into a film. What is remarkable here - besides the derogatory description of lesbians - is the comparison of lesbians to prostitutes. In the chapter "Der Ball der schwarzen the con " [The Blorzen Dreiecke " The Black Triangles' Bal], the Jewishchanson-singer Fania Fénelon, who had been since January 1944 ordered to play music in Auschwitz-Birkenau, write about her encounters with the "schwarzen Winkeln" "Black Triangles") at the camp The scenery starts at the block of latrines, where Black Triangle Hilde reigns over all the latrines as Kapo. She is described as a "dull brute", anti-Semitic and utterly obscene: "Hilde and Inge smirk and gawk at us: drunk, their breasts exposed, fondly entangled" (Fénelon 1982, 259) ${ }^{1}$. And in all of this, Hilde's "favourites" - also women with black triangles - emulate her.

In the summer of 1944, Hilde hires Fania and the orchestra for a nocturnal "ball" at the "asocial" block On the night in question, according to Fénelon's description, the group of those that turned up from the "asocil" block is composed "Cerman prostitute, Aryan had "turned into homosexuals certainly because of deficiency, but also because a couple of them were enough to force this ordinance. Those who refused were battered so that they would rather join in, especially the younger ones" (Fénelon 1982, 266). The promiscuous head of this "weird women's club" is Georgette aka George, "a real petty souteneur", whose falsetto voice makes the others giggle, while the rest of the "den's drones" rather speak with the most low-pitched voices possible to appear "more masculine" (262). There is no shortage of alcohol so that the dancing becomes more and more lascivious and soon turns into "loathsome sex-scenes, nauseating to eyes and ears" (266). An approaching guard cuts the goings-on short. ${ }^{3}$

Olga Lengyel also mentions the "Asocial's" block and nocturnal parties. Lengyel shares Fénelon's moral condemnation of these "dance-orgies" but is more tempered. According to Lengyel, one of the instigators of those "balls" is a Polish countess, who looked and behaved like a "handsome guy around 30 ". By courting Lengyel, who escaped her, the countess was apparently looking for a substitute to replace her girlfriend, who had been killed in the camp. For the SS, this woman served as a source of amusement. It seems that she had arrived at the camp in men's clothes and the SS wanted to put her in the men's camp. She vehemently protested and, in return, the SS forced her to "prove" that she was a woman. Later on, they had fun watching the "simmicks of this virago", as Lengyel refers to it amongst the other women (Lengyel 1972, 191ff).

Another example can be found in Krystyna Żywulska's novel Wo vorher Birken waren [There Used to be Birch Trees]. Żywulska limits herself to the derogatory description of two women in particular - both were wearing a black triangle. She provides the following observation made in the latrine-shack after her arrival at the main camp of Auschwitz in 1943

On the planks between the holes perched a German with a black triangle - a downright masculine type. A very feminine girl with long hair was sitting on her knees. She steadily looked at her partner and then, all of a sudden, kissed her on the lips. That kiss took ages. It is quite hard to imagine something more hideous. This kind of love in that setting! (̇̇ywulska 1980, 66) ${ }^{4}$

In contrast, the second episode describes a Kapo, wearing pants and a black triangle, who tries to seduce a girl with potatoes - a delicacy at the camp. But "her leering gaze and courteous gestures" revealed the Kapo's intentions and the girl fled (118).

\section{PLATONIC FRIENDSHIPS VS. SAME-SEX RELATIONSHIPS}

What all these descriptions have in common - and numerous others could be added - is that the writers disapprove of individual or groups of women, whom they characterise as lesbian (see Póltawska 1993. Janz 1994). These women are clearly assigned eithe to "Black Tringle assigned either lesbian = asocial made by the SS was targely hation of female homosexuality seemed to assure their moral superiority. On the other

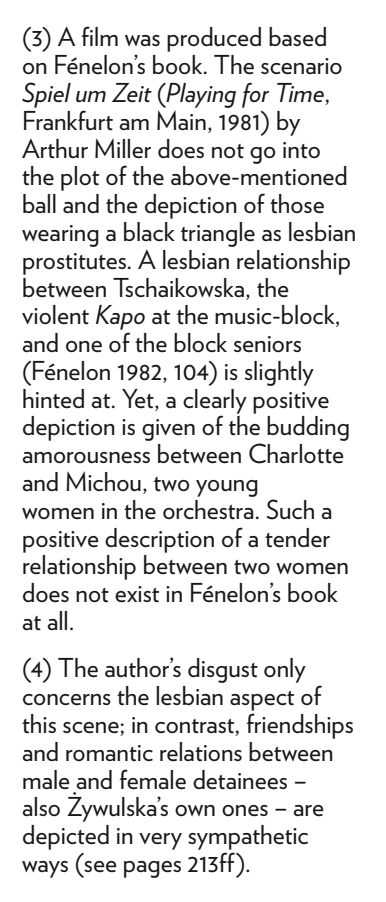


hand, one must not neglect that the "Aryan" prisoners in Auschwitz were part of the camp's "aristocracy" because, in principle - and in contrast to the Jewish inmates even the "privileged ones" in the orchestra - were not bound to the gas chambers.

At the same time, relationships and friendships amongst the political inmates are portrayed as asexual and "pure". The more asserting the way this is expressed, the stronger, presumably, the fear of being perceived as a lesbian. Margarete Buber-Neumann, who was herself a political detainee in Ravensbrück, writes in her memor Milena, Kafkas Freundin:

Passionate friendships were as common amongst the Politicals as they were amongst the Asocials or the Criminals. Mostly, the only difference was that the relationships between the Politicals - in contrast to those between the Asocials or the Criminals remained platonic, while the others were quite openly lesbian. [...] Asocial couples were usually composed of a masculine part and a clearly feminine part. In the Asocial's jargon, the masculine part was called "kesser Vater" [butch]; she emphasised her broad shoulders and narrow hips, and wore her hair as short as possible. She spoke with a

Generally, the "openly lesbian" conduct thus remains reserved for the category of Asocial and the Criminal, while friendships amongst the Political prisoners supposedly remained pure and platonic. At the same time, each woman depended on friendships to have a chance to survive at all and Buber-Neumann's text straightforwardly recounts her close friendship with the Czech journalist and Kafka-translator Milena Jesenska. It might be for this very reason that the demarcation between "acceptable" and "objectionable" forms of friendship was required. ${ }^{5}$ In my conversations with former Ravensbrück-detainees the taboo of sexual relations amongst the Political inmates became very clear - and that there was no space for homosexuality in their self-perception. Georgia Tanewa ${ }^{6}$ who came to Ravensbrück as a Politica inmate mid-1942, put it as follows:

At the international political block where I was, nobody talked about things like that at all. In case you knew someone, who was maybe homosexual, you were diplomatic and kept silent. You could not know it, indeed you did not want to know it. You discreetly ignored it. Maybe this had to do with the puritanism of the Left at the time. Homosexuals rarely revealed themselves anyway, for obvious reasons.

I was very young at the time (19 years old) and I did not even know that homosexuality existed. It was not perceptible at our block at all, by the way. Of course, there were friendships amongst women, but you really never considered that they could be homosexul. Politics always took the centre stage. Homosexulity was a strictly private is It wa like that at our brote issuc It was the to actually never got together. We did not mix with those who wore a black triangle. Seen from today's point of view, that was of course unfair. As mentioned before, there were couples in the camp, usually amongst those with a black triangle. Amongst the Political inmates, there were steady friendships, but you would never know if they were homosexual. Sexual practices were impossible at the politicalblock anyway - among the A ng the Asoo not know.

When you had been at the camp for some

time and in a block, where things were

somewhat orderly, which was the case for some of the blocks until, let's say, 1944, frien were being made, you definitely had a close friend. But that did not necessarily mean that there was anything erotic about it. Of course, somewhere in the unconscious, you had ideas about that, too, but you would have never let them surface. But that is what I'm saying from today's point of view.

You had the need for a close relation, for protection and tenderness, some kind of surrogate protector what women still see in men until today. It seemed more like playing but he 作 seeing all that through today's eyes.

After some time in detention, you needed some kind of role allocation, the way it exist for men and women in society. Women that were strong and somehow wanted to lead started to perform like men. We called Gertrud Peter, for example.

I am sure that she was not homosexual in the way we understand the term today - but we called her Peter. She was a Political inmate, she was accused of breach of contract because she had not shown up at work somewhere and the Gestapo at Ilmenau categorised her as a Political inmate. She was at the German political block 4. She came to Siemens ${ }^{7}$ and we worked there together She just had those boyish ways. She had very short hair and combed it smooth to attact attention: Iboklike a boy. If he was relly homosext I do not know. We actually did have that kind or gane going on, that she was in love with me, you also flirted etc., but I definitely interpreted it as notin (In conversation with G. Tanewa on 3 March 1987)

Provided that the taboo of sexual relations amongst the Political inmates is broken at all, those kinds of relationships are presented as camp-induced and temporary, while they seemed to be overt homosexuality amongst the "Asocial". Whereas the "masculine" demeanour of a few Political inmates is regarded as something positive and did not call into question their heterosexuality, the very same thing is considered a proof of homosexuality amonost the "Asocial”.The same mechanisms could be observed even more so in moverere otherhand, were severelyjudged by both the SS and other detainees (Kogon 1983, 284).
(7) Siemens \& Halske built an camp proximity at which besides civilian workers, 2500 camp 
The lines of tension and conflict between detainees ran not only between the individual categories of detention, but also between the ordinary inmates and the Kapos, who were disposed of particular privileges and authority according to their specific function and position. Regardless of how an individual Kapo acted, tension were inevitable. This was an integral part of the SS-system: to always play detainees off against each other to prevent solidarity amongst them and, above all, to prevent any resistance to the SS. ${ }^{8}$ The power imbalance between prisoners could also result in unprivilegedinmates' offering to exchange sexand heve in their fight for survival. Such an example of prostitution is described by Buber-Neumann:

During the penultimate camp year, when Ravensbrück started to turn chaotic, I hear about a case of lesbian procuring. He, or rather she, was named Gerda, but called herself "Gert" and provided several women with love at once. However, she did not do that out of love at all and even less so for free. She got herself paid for it. Every Saturday and Sunday the loved ones - in duty bound - supplied the spirited Gert with their rations of margarine and sausage, which were only received on weekends. (Buber-Neumann 1977,50

Mainly due to their position, Kapos also tried to "buy" love. For example, Antoina R., a Czech Jew, reports on a German lesbian Kapo in Auschwitz, who was wearing a black triangle. The report does not disclose why she had been detained, however. The Kapo provided Antonia R. with an additional ration of bread:

Each night, the Kapo came to my bed and she always took my hand in her hand, telling me that I was her favourite, and I was so naive, I believed what she said until one day someone called my attention to it: Be careful, they can be very dangerous, too, they are homosexual, and that is something different. It was the first time in my life that I had met such people, and then the way I was told, that this was, again, for me no good. (Fürstenberg 1986, 25)

Another case is narrated by Olga Lengyel, who gives the example of a Polish professor of physics in Auschwitz - an attractive, intelligent, and delicate woman. One of the (female) Kapos was supposedly courting her. The professor knew that she would at least escape hunger if she accepted the offer: "She must have fought a long battle with herself against this temptation, but in the end, she gave in", suspects Lengyel $(1972,191)$. After a few weeks, she would even declare that she could not live without her "wife" any more.

\section{POSITIVE ACCOUNTS}

Margareta Glas-Larsson recounts another relationship of this kind in an excep(8) About the social structure
at the camp see Sofsky 1993,
115-190 tionally positive light. Glas-Larsson, an Austrian Jew, was arrested in Prague and first deported to the concentration camp Theresienstadt before she arrived in
Auschwitz in May 1943. In her memoir, Ich will reden (I want to speak), she reports on her "exceptional friendship" with the German communist Aurelia Reichert-Wald", referred to as Orli, who is described as a lesbian in other memoirs as well. ${ }^{10}$ Only from the perspective of being a persecuted Jew was it possible for Glas-Larsson to also write - even though still in a very limited way and qualified as situational - on her temporary sexual relationship with Orli Reichert, who was the camp senior at the prisoner infirmary of Auschwitz-Birkenau:II

I had an exceptional friendship with Orli, for my part an immense sympathy in particular because her soul seemed so very appealing to me. She was never mean. [. ] Orli was a human that I loved so dearly, no matter if woman or man. These are feelings that cannot be put into words, actually. And those feelings can only occur in such extreme situations, they do not exist in normal life, really. [...] And I believed all the way that it was my love for Orli that so strongly kept me alive. (Glas-Larsson 1981, 149)

The following quote gives a very vivid and graspable account of how the extreme conditions at the camp led to romantic relationships between women:

It is because the instinct of survival is an incredibly strong instinct. In fact, it was the most developed instinct in the camp. It was closely connected to food, of course. And an incredible need for intimacy, no matter if provided by a man or a woman. And Orli was the love of my life and I am not embarrassed about that - not at all... If you are a little bit into psychology, you understand that.

Those were dire conditions. We lacked warmth, human warmth and tenderness; things you are usually provided with in childhood already. And then, later, by the husband etc. It was really bad. And that is why you attached yourself to someone. [...] One night I asked Orli if I might stay with her. And I lay down with her. Grete Hamburger was in the room, too. That is a woman I knew from the old times in Prague. And that night the sky was deep red and I do not know if it was because the SS burned the new arrivals from Hungary and burned Jewish children or if the Sonderkommando burned so many people. Anyway, I was not unhappy, on the contrary. I was so terribly happy that night for I could stay with Orli. I also said to her over and over again: "You are the human being that I love the most, no matter if you are male or female."

Please, I mean that literally. That is what I said. We also exchanged caresses and Grete Hamburger witnessed all of it and, afterwards, she always looked at me strangely - only me. I had known her from times in liberty and all of a sudden I felt ashamed because she sometimes looked at me so very viciously. If it was jealousy - I do not know. I did not mind that Grete Hamburger was in the same room. I had probably lost my inhibitions or I was too affected by all those caresses. And the sensation of feeling human warm th I think that Orli did all of that for me out of compassion and great sympathy, and because she always said: "You are so pretty Dolly You have great face." And so on. I just believe she did it because I was Jewish and because I always feared for Schoschi [her husband, who was also detained in Auschwitz], and there were

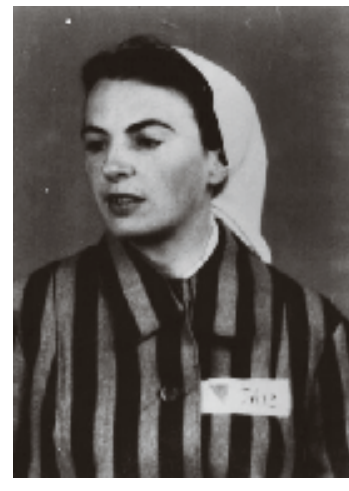

- Orli (Aurelia) Reicher 26 March 1942

(9) Aurelia Reichert-Wald, born in Trier in 1914, German communis serving a sentence of four and a half years in jail, came first to the camp of Ravensbrück and, in 1942, to Auschwitz-Birkenau with he year 194 , she became camp senior of the prisoners infirmary
Physically and psychologically broken by her time in detention, she died on January 1, 1962. See
Steger \& Thiele 1989. (10) According to Lengyel (1972,
191ff), Orli Reichert regularly participated in nocturnal "dance

(11) Gerhard Botz, historian and at this point quite rightly notes:
"Had Margareta Glas-Larsson got into the oppressive machinery
of the SS-state as a so-called Asocial, a vagabond, a prostitute, a homosexual, someone work-shy etc. or as an apolitical criminal
she could not have chosen to make the story of her life public today, using it as a way out of her traumatic state. And even if, she
would have aimed to bend her life story and make it completely
political. The history of inhumane apolitical prosecution during historically worthy." (Glas-Larsson $1981,64)$ 

(12) I want to thank Christa
Schulz, Ravensbrück Memorial Site, for the information. The example also shows the
importance of interviews with
witnesses, especially regarding
such taboo-issues.

(13) See Langbein 1972,2 247ff. never heard or read anything negative" about Orli Reichert. "that despite her high rank in the camp, she never forgot
that National Socialism was the that National Socialism was the
common enemy of all detainees

(14) This block was established in 1942 according to the Night 1942 concerning of 4 - ebruary countries. The order signed by Keitel, head of the OKW Armed Forces) determined that crimes against the Reich were to be punished by death wenalty. Relatives did not get any information as to the fate or the whereabouts of detainees (15) The eerie image of Knol into question by the author's report, which is in part factually wrong and, besides, peppered
with prejudices, assertions and generalizations. She pulls all the prisoner groups to pieces - apart
from the Dutch. She refers to
German detainees as "llll lesbian" (16) This contradicts the
information given by the
Attorney General, see nex Attorney General, see nex many different reasons for it, which are way too difficult to put in words. But it was like that. And it was the case amongst other detainees, too, that I know for sure. I was not present, but I know it, that they stuck together. And that was the right thing to do, really. (176ff)

Similarly positive was the account from Krystyna Usarek, which she gave at a seminar at Ravensbrück Holocaust Memorial Site in the year 1993. The Polish journalist was arrested at the age of 20 in August 1944. Only when a fellow detais jourking as retainee working as room service "proposed" to her, did she realise that there were lesbian women in the cann, and this is what probably lowing observation, which must have strongly impressed her. She reported on the maintain "order") and a woman that was referred to as bed-political in camp-jargon the latter had been arrested due to her relation with a Czech man. All "Bed-political" inmates were supposed to be released from the camp at the end of February 1945 but this woman jumped off the open truck that would have guaranteed freedom only so she could stay with her lover.

\section{THE CASES OF KAPO KÄTHE KNOLL AND ELEONORE BAUR}

While camp senior Orli Reichert was well respected by fellow detainees despite her sexual relations, ${ }^{13}$ other cases provoked conflict. An example for that is Käthe Knoll, a block-senior of Ravensbrück, who had lesbian relations - at least at the camp. At times, Knoll was block-senior of the so-called "cloak-and-dagger" block, which was mainly inhabited by members of occupied countries. ${ }^{14}$ From fall 1944 until the end of the war, she was camp senior of the so-called industrial complex a sub-camp adjacent to Ravensbrück, which featured housing blocks as well as SS and armament factories, at which the inmates were forced to work.

Germaine Tillion, who was detained at the "cloak-and-dagger" block describes Knoll as "diabolic" (Tillion 1946, 33) and the former Dutch Ravensbrück (Women's camp of Ravensbrüch). Berendsen writes the late "tall Rus. (W" lady sove who the herself "was rady-love, who terrorised the whole block at night, and that Knoll cent the bunker and punishment-block because of her" (Berendsen 1946, 88) ${ }^{15}$ Knoll's Reimann, the appointed room senior of block 5 of the industrial complex at the onset of 1945, assured me.

According to Reimann's descriptions, Knoll was a political detainee and a communist ${ }^{16}$ and she attempted to prevent Reimann and others from smugoling certain women out of transports that were headed to extermination camps. They then confronted Knoll, who atter allhadprotecther girf iendawell Afterways, The confonted Knll, who atter als, she relationship between a so-called camp policewoman (meaning a Kapo that had to lover, who actually existed, was not really Russian, though, but Dutch, as Barbara

in rescue operations ever again. After the war, Käthe Knoll was convicted of "crimes against humanity" in the GDR and spent 18 years in jail. Her love affair at the camp did not play any obvious role in this sentence however.

Even more extreme than the above examples of relationships among Kapos and ordinary inmates was the power difference between detainees and SS-supervisors (Schwarz 1994). Inmates were without protection, at the mercy of their supervisors, and had to obey their orders without fail; otherwise, they suffered all kinds of assaults, including sexul ones. Many of the prisoners were especilly stumed by the fact that other women - in their role of supervisor - would take part in the SS' crimes and that they equalled SS men in the sadistic cruelties they perpetrated. The hypothesis that women were "naturally" more peaceful than men was thereby quite painfully disproven.

In some of the reports of former detainees there are allusions to the supervisors - one of them was Irma Grese - sexually assaulting detained women (Langbein 1972, 447-449). It seems understandable that women experienced sexual coercion as particularly offending and degrading as, generally, they were (and still are) much more than men defined by their biological functions, for example, their ability for childbirth ${ }^{18}$ References regarding female offenders in general (not only SS-women) cutees of the Nazi Regime (VVN):

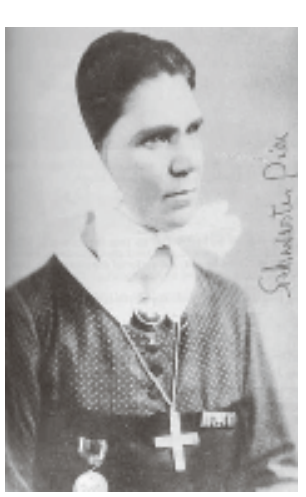
Eleonore Baur, also
known as 'Sister Pia' known as 'Sister Pia' abuse during her post-war trial (Holzhaider 1994). This text is a translated excerpt from Schoppman's book Nationalsozialistische Sexualpolititu und weibliche
Homosexualität (Pfaffenweelert Centaurus, 1991, revised edition 1997), p. 244-254 (from section "Zur Situation
lesbischer Frauen im KZ", p. 227-257).

Baur Eleonore, referred to as Sister Pia, sexully assaulted (female) detainees, abused and denunciated them, and participated in Dr. Rascher's underwater experiments. (VVN-Investigation Service Nr. 9, Sept./Oct. 1950, p. 8)

The former catholic Sister was one of the earliest supporters of Hitler. As a party clerk, she was part of the Hitler-putsch in 1923 and, as the only woman ever, was awarded the legendary Blood Order as well as, later on the Golden Partybadge After1938, Eloonote had free access to the camp of Dachau, forced detainees to work for her, and participated in SS doctor Rascher's murderous experiments that included 200 inmates. Although other sources mentioned sexual assault, too - but exclusively against men, among them also a pink-trianglearren for those women not to "be part of transport". Knoll would not interfere
(17) Written notice of the Attorney General, GDR, 20
June 1988: "On 5 July 1948, the Regional Court Dresden [....] convicted the nurse Katharina to 18 years of jail. The sentence was based on evidence that the detainees to camp administration at the concentration camp of Ravensbrück and that she had
also abused some of them on various occasions. Furthermore since Katharina Knoll (she got married to Hans Angeler in
August 1945) held the function of camp senior, in the spring of 1945 , she assisted in the that were subsequently gassed. Eventually, according to her own plea, she became part of beginning of March 1945 and wore their red armband. As far as I can tell, questions concerning
homosexuality were not debated during the trial. For the rest, the convict had given birth to 1933 , and 1935, and to a girl in 19337. Each of the children grew up with its respective father.
During the Dresden trial Mirs Angeler explained that the reason why she had been taken to the concentration camp in
the first place was alleged racial defilement. According to her recollection, the preventive Führer's integration processs and nation-destructive conduct?" For against Knoll, who died in 1952 in Waldheim prison (East Germany) at the age of 47, see Eschebach

(18) The SS systematically femininity and identity to camp-reports give evidence of camp-reports give evidence of
psychological pain triggered by
the forced shaving of their hair. In addition, a lot of women did not get their period any more due to
malnutrition and many of them feared that they had become 


\section{WORKS CITED}

- Berendsen, Anne, Vrouwenkamp Ravensbrück, Utrecht: De Haan, 1946.

- Buber-Neumann, Margarete, Milena, Kafkas Freundin, München: Langen Müller, 1977.

- Eschebach, Insa, 'Das Stigma des Asozialen. Drei Urteile der DDR-Justiz gegen ehemalige Funktionshäftlinge des Frauenkonzentrationslagers Ravensbrück', Beiträge zur Geschichte der nationalsozialistischen Verfolgung in Norddeutschland 4, 1998, 69-81.

- Fénelon, Fania, Das Mädchenorchester in Auschwitz, München: Deutscher Taschenbuch Verlag, 1982.

- Föster, Michael, 'Schwester Pia und die Sklaven', in: Rainer Schilling (ed.), München von Hinten. Berlin: Bruno Gmünder Verlag, 1982, 51-52.

- Fürstenberg, Doris (ed.), Jeden Moment war dieser Tod. Interviews mit jüdischen Frauen, die Auschwitz überlebten, Düsseldorf: Schwann, 1986

- Glas-Larsson, Margarete, Ich will reden. Tragik und Banalität des Überlebens in Theresienstadt und Auschwitz, Gerhard Botz (ed.), Vienna: Molden, 1981

- Holzhaider, Hanz, 'Schwester Pia. Nutzniefzerin zwischen Opfern und Tätern', Dachauer Hefte 10(10), 1994, 101-114.

- Janz, Ulrike, 'Lesben/lesbische Verhalten in nationalsozialistischen Konzentrationslagern - Zeugnisse überlebender Frauen und was sie uns (nicht) sagen', in Madeleine Marti, Angelika Schneider, Irena Sgier \& Anita Wymann, Querfeldein. Beiträge zur Lesbenforschung, Bern: eFeFVerlag, 1994, 114-118.

- Kogon, Eugen, Der SS-Staat. Das System der deutschen Konzentrationslager, München: Heyne, 14th edition 1983.

- Langbein, Herrmann, Menschen in Auschwitz, Vienna: Europa Verlag, 1972

- Lengyel, Olga, Five Chimneys: A Woman Survivor's True Story of Auschwitz, London, New York: Mayflower, 1972.

- Müller, Wolfgang, Auschwitz. Geschichte und Wirklichkeit des Vernichtungslagers, Reinbek bei Hamburg: Rowohlt, 1980.

- Półtawska, Wanda, Und ich fürchte meine Träume, Abensberg: Maria Aktuell Verlag, 1993.
- Sofsky, Wolfgang, Die Ordnung des Terrors: Das Konzentrationslager, Frankfurt am Main: S. Fischer Verlag, 1993.

- Schwarz, Gudrun, 'SS-Aufseherinnen in Nationalsozialistischen Konzentrationslagern (1933-1945)', Dachauer Hefte 10(10), 1994, 32-49.

- Steger, Bernd \& Günter Thiele, Der dunkle Schatten. Leben mit Auschwitz. Erinnerungen an Orli Reichert-Wald, Marburg: SP-Verlag, 1989.

- Tillion, Germaine, Ravensbrück, Neuchatel: Cahiers du Rhône, 1946.

- Żywulska, Krystyna, Wo vorher Birken waren, München: Kindler, 1980.

\section{FURTHER REFERENCES}

- Eschebach, Insa, 'Homophobie, Devianz und weibliche Homosexualität im Konzentrationslager Ravensbrück', in Insa Eschebach (ed.), Homophobie und Devianz. Weibliche und männliche Homosexualität im Nationalsozialismus, Berlin: Metropol Verlag, 2012, 65-78.

- Hájková, Anna, 'Das verborgene Leben der Eleonore Behar’, 27 January 2017, http://www.Isbttiq-bw.de/2017/01/27/das-verborgene-lebender-eleonore-behar/ (accessed 20 July 2017).

- Marhoefer, Laurie, 'Lesbianism, Transvestism, and the Nazi State: A Microhistory of a Gestapo Investigation, 1939-1943', American Historical Review 121, 2016, 1167-1195.

- Schoppmann, Claudia, Days of Masquerade: Life Stories of Lesbians during the Third Reich, New York: Columbia University Press, 1996.

- ---, 'Elsa Conrad, Margarete Rosenberg, Mary Pünjer, Henny Schermann: Vier Porträts', in Insa Eschebach (ed.), Homophobie und Devianz. Weibliche und männliche Homosexualität im Nationalsozialismus, Berlin: Metropol Verlag, 2012, 97-111.

- ---, 'Zwischen strafrechtlicher Verfolgung und gesellschaftlicher Ächtung: Lesbische Frauen im “Dritten Reich”, in Insa Eschebach (ed.), Homophobie und Devianz. Weibliche und männliche Homosexualität im Nationalsozialismus, Berlin: Metropol Verlag, 2012, 35-51.

- Schwartz, Michael (ed.), Homosexuelle im Nationalsozialismus. Neue Forschungsperspektiven zu Lebenssituationen von lesbischen, schwulen, bi-, trans- und intersexuellen Menschen 1933 bis 1945, München: Oldenbourg, 2014. 